\title{
Journal of Civil \& Environmental Engineering
}

\section{Waste Removal and Oxygen Condition in a Natural Water Purification System}

\author{
Yeh $\mathrm{TY}^{1 *}$, Chen $\mathrm{KF}^{2}$ and Lin $\mathrm{CL}^{1}$
}

${ }^{1}$ Department of Civil and Environmental Engineering, National University of Kaohsiung, Kaohsiung City, Taiwan

${ }^{2}$ Department of Civil Engineering, National Chi Nan University, Nantou 54561, Taiwan

*Corresponding author: Yeh TY, Department of Civil and Environmental Engineering,National University of Kaohsiung, Kaohsiung 811, Taiwan, Tel: 886-7-591-9536; Fax: 886-7-591-9376; E-mail: tyyeh@nuk.edu.tw

Rec date: Mar 31, 2014; Acc date: Apr 29, 2014; Pub date: May 06, 2014

Copyright: () 2014 Yeh TY, et al. This is an open-access article distributed under the terms of the Creative Commons Attribution License, which permits unrestricted use, distribution, and reproduction in any medium, provided the original author and source are credited.

\begin{abstract}
Emergent incident of fish kill was occurred in the detention pond of natural water purification system. The objective of this study was revealed the cause of the incident.Novel measurements unprecedentedly employed in this study including SOD to measure sediment oxygen decay PCR to find out sediment microbial activity, SEM, EDX, and FTIR to view the macrophyte rhiyphere root surface to understand the pollutant adsorption. Algal bloom was the main reason to induce serious fish kill Particle size analysis demonstrated greater particles were setting in the upstream.Chlorophyll A, COD, SS, phosphorus, E coli was in descending of following the stream direction. The end of measuring point, detention pond, demonstrated the serious eutrophication which leads to diurnal $\mathrm{pH}$ and $\mathrm{DO}$ fluctuation to induce anoxic condition at night which induced fish kill. Sediment oxygen uptake (SOD) also measure to fine vertical oxygen profile. SEM, EDX, and FTIR results indicated the major functional groups of submergent macrophyte reed root were carboxyl, carbonyl, and phenol which could adsorp various pollutants.
\end{abstract}

Keywords: Constructed wetland; Algae; Sediment; Sediment Oxygen Demand (SOD)

\section{Introduction}

Constructed wetlands, nature water purification systems and novel green remediation approaches, have commonly employed in Taiwan and worldwide for water polishing.Several constructed wetlands have been listed as nation wetlands and to be special protected and managed. Constructed wetlands possess organic matters (BOD and COD), particulate matters (SS), nutrients (Nitrogen and Phosphorus), heavy mental $(\mathrm{Cu}$ and $\mathrm{Zn})$, pathogen idicator (E. coli) and pharmacypheutical personal care products (PPCPs) mitigation ability [1-4]. Constructed wetlands have long been a black box and pollution degradation was not revealed.Recently, numerous studies have conducted to reveal the black box.

A serious fish kill occurred in the University detention pond which induced water quality was significantly reduced. The university suspected toxic algae was the cause of fish kill. An investigation project was initiated to scrutinize fish kill and proposal of water related monitoring was conducted. The objective of this study was aiming to the oxygen status in the wetland system and the myth of fish kill. To our best literature review, none if any conducted the following novel measurements unprecedentedly employed in constructed wetland including SOD to measure sediment oxygen decay PCR to find out sediment microbial activity, SEM, EDX, and FTIR to view the macrophyte rhizhere root surface to understand the pollutant adsorption. By virtue of aforementioned resulted, real cause of fish kill can be revealed.

The objective of this study was mainly focused on the cause of fish kill in natural water purification systems related to oxygen concentration. Algal growth influence factors were also monitored which was provided for water bodies eutrophication. This monitoring study can be referenced by natural water purification systems for fish kill and eutrophication.

\section{Materials and Methods}

\section{Study site}

The constructed wetlands are situated in University of Kaohsiung campus $\left(22^{\circ} 73^{\prime} \mathrm{N}, 120^{\circ} 28^{\prime} \mathrm{E}\right)$ the study site is shown in Figure 1 . The length, width, average depth, and flow velocity were $585 \mathrm{~m}, 5.2 \mathrm{~m}, 0.5$ $\mathrm{m}$ and $67.5 \mathrm{~m} / \mathrm{hr}(1.88 \mathrm{~cm} / \mathrm{s})$ while the detention pond at pointhas the depth as $1.2 \mathrm{~m}$. The flow rate was?

\section{Water quality analysis}

Water parameters including organic matters (BOD and COD), particulate matters (SS), nutrients (Nitrogen and Phosphorus), chlorophyll A, and pathetic indicator (E. coli) were investigated.

\section{Sediment oxygen demands and sediment quality analysis}

SOD analysis: The schematic setup of SOD measurement is shown in Figure 1. It can detect sediment oxygen demand and understand the microbial activity.

\section{Macrophytes surface adsorption properties detection using Scanning Electron Microscopy(SEM) and Energy Dispersive $\mathrm{X}$-ray (EDX) spectroscopy}

Pretreated macrophyte samples were gold-coated for SEM observation with qualitative EDX analysis. Specifically, grinded and dried samples were mounted on carbon tape and sputter coated in gold. A Hitachi S-4300 SEM (Tokyo, Japan) was used to capture micrographs. The elements $\mathrm{C}, \mathrm{O}, \mathrm{Cu}$, and $\mathrm{Zn}$ were detected using a 
Page 2 of 4

SEM coupled with an EDX spectroscopy at an acceleration voltage of $15 \mathrm{kV}$.

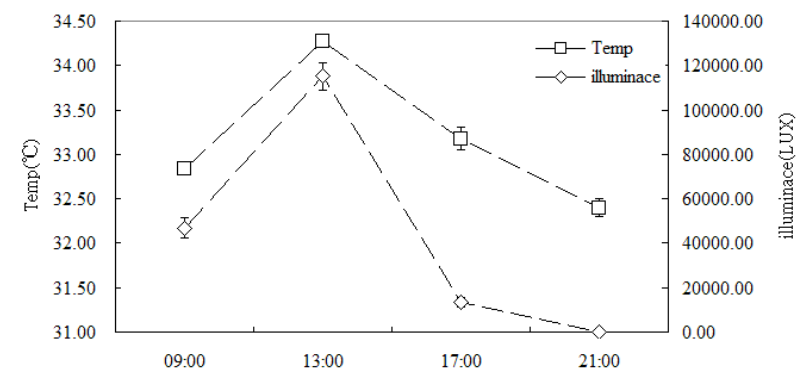

Figure 1: Diurnal water quality variation.

\section{FTIR}

Fourier Transform InfraRed (FT-IR) regards as the preferred method of infrared spectroscopy. In infrared spectroscopy, IR radiation is passed through a sample. Some of the infrared radiation is absorbed by the sample and some of it is passed through (transmitted). The resulting spectrum represents the molecular absorption and transmission, creating a molecular fingerprint of the sample. Like a fingerprint without two unique molecular structures produce the same infrared spectrum. This makes infrared spectroscopy useful for several types of analysis. Infrared spectroscopy can result in a positive identification (qualitative analysis) of every different kind of material. In addition, the size of the peaks in the spectrum is a direct indication of the amount of material present. With modern software algorithms, infrared is an excellent tool for quantitative analysis.

\section{Data and statistical analysis}

Data were evaluated relative to the control to understand their statistical variation.A triplicate of water and sediment samples were measured and recorded for statistical analyses.Statistical significance was assessed using mean comparison test. Differences between treatment concentration means of parameters were determined by Student's $t$ test. One-way ANOVA was also employed to show the variation among sample groups, level of $\mathrm{p}<0.05$ considered statistically significant was used in all comparisons. Means are reported mean \pm standard deviation. All statistical analyses were performed with Microsoft Office EXCEL 2007.

\section{Results and Discussion}

\section{Water parameter analysis}

The results of these measurements are showed in Table 1. Algal growth related water parameters chlorophyll A, COD, turbidity, SS were in increasing order from upstream to detention pond which induced fish kill. Wastewater after treat with wetland system effluent level BOD concentration general below $10 \mathrm{mg} / \mathrm{L}$, TSS concentration below $30 \mathrm{mg} / \mathrm{L}$. TN concentration if $27 \mathrm{mg} / \mathrm{L}$. The average removal efficiency is $42 \%$. TP removal is around $50 \%[5,6]$. Algal growth due to photosynthesis and algal respiration affect. Diurnal $\mathrm{pH}$ and $\mathrm{DO}$ monitoring results are showed in Figure Algal photosynthesis produced $\mathrm{CO} 2$ and oxygen to induce $\mathrm{pH}$ and $\mathrm{DO}$ rising in the day time. DO increased was related to oxygen producing and $\mathrm{pH}$ increased was due to algae used up $\mathrm{CO} 2$ inducing $\mathrm{pH}$ dropping.In the night time, algal respiration enhanced $\mathrm{CO} 2$ production to convert generation of carbonic acid leading dropping $\mathrm{pH}$.

\begin{tabular}{|c|c|c|c|c|c|c|}
\hline & A & B & C & D & E & $F$ \\
\hline $\begin{array}{l}\text { Temp. } \\
\left({ }^{\circ} \mathrm{C}\right)\end{array}$ & $\begin{array}{l}30.9 \quad \pm \\
2.1\end{array}$ & $\begin{array}{l}35.2 \quad \pm \\
1.9\end{array}$ & $\begin{array}{ll}35.4 & \pm \\
2.6 & \end{array}$ & $\begin{array}{l}35.7 \quad \pm \\
2.7\end{array}$ & $\begin{array}{l}37.4 \\
2.8\end{array}$ & $33.5 \pm .7$ \\
\hline $\begin{array}{l}\mathrm{DO} \\
(\mathrm{mg} / \mathrm{L})\end{array}$ & $\begin{array}{ll}6.23 & \pm \\
2.7 & \end{array}$ & $\begin{array}{l}8.48 \quad \pm \\
3.1\end{array}$ & $\begin{array}{l}17.93 \quad \pm \\
3.9\end{array}$ & $\begin{array}{l}18.65 \quad \pm \\
3.5\end{array}$ & $\begin{array}{l}17.15= \\
3.4\end{array}$ & $\begin{array}{l}14.71 \quad \pm \\
4.2\end{array}$ \\
\hline $\mathrm{pH}$ & $\begin{array}{ll}8.24 & \pm \\
1.87 & \end{array}$ & $\begin{array}{l}8.48 \quad \pm \\
1.98\end{array}$ & $\begin{array}{ll}8.68 & \pm \\
1.95 & \end{array}$ & $\begin{array}{ll}8.79 & \pm \\
1.80\end{array}$ & $\begin{array}{l}8.65 \\
2.12\end{array}$ & $\begin{array}{l}8.30 \\
2.04\end{array}$ \\
\hline
\end{tabular}

Table 1: water quality analysis results.

\section{Water quality and algal species monitoring}

Chlorophyll A concentration for A, B, and C were $192 \pm 71.8,319.7$ \pm 91.6, 307.2 $\pm 68.1 \mu \mathrm{g} / \mathrm{L} . \mathrm{A}, \mathrm{B}$, and C turbidity were $21.3 \pm 6.3,27.5 \pm$ $6.3,27.0 \pm 11.5 \mathrm{NTU}$ while SS were17.7 $\pm 2.5,30.7 \pm 7.8,34.3 \pm 10.4$ $\mathrm{mg} / \mathrm{L} . \mathrm{COD}$ concentrations for $\mathrm{A}, \mathrm{B}$, and C were $19.1 \pm 6.7,29.1 \pm 8.8$, $23.0 \pm 10.1 \mathrm{mg} / \mathrm{L}$. Total poseurs concentration for $\mathrm{A}, \mathrm{B}$, and $\mathrm{C}$ were $192 \pm 71.8,319.7 \pm 91.6,307.2 \pm 68.1 \mu \mathrm{g} / \mathrm{L}$. E. coliconcentrations for A, $\mathrm{B}$, and $\mathrm{C}$ were $28,333 \pm 7,505,8,333 \pm 8,082,2,333 \pm 2,309 \mathrm{CFU} / 100$ $\mathrm{mL}$. The main processes for the removal of SS are sedimentation and filtration within systems. Phosphorus removal in wetlands might be induced by the plant uptake, accretion of wetland soils, microbial immobilization, retention by root bed media, and precipitation in the water column (Table 2).

\begin{tabular}{|c|c|c|c|c|c|c|}
\hline & A & B & C & D & $\mathbf{E}$ & $\mathbf{F}$ \\
\hline $\begin{array}{l}\text { Chorollphyl } \\
\mathrm{A}(\mu \mathrm{g} / \mathrm{L})\end{array}$ & $\begin{array}{l}178.1 \pm \\
68.1\end{array}$ & $\begin{array}{l}192.6 \pm \\
71.8\end{array}$ & $\begin{array}{l}336.5 \pm \\
82.1\end{array}$ & $\begin{array}{l}319.7 \pm \\
91.6\end{array}$ & $\begin{array}{l}295.4 \pm \\
93.3\end{array}$ & $\begin{array}{l}307.2 \pm \\
68.2\end{array}$ \\
\hline Turbidity (NTU) & $\begin{array}{l}10.0 \pm \\
3.6\end{array}$ & $\begin{array}{l}21.3 \quad \pm \\
6.3\end{array}$ & $\begin{array}{ll}32.3 & \pm \\
7.5 & \end{array}$ & $\begin{array}{ll}27.5 & \pm \\
6.3 & \end{array}$ & $\begin{array}{l}25.1 \quad \pm \\
4.9\end{array}$ & $\begin{array}{l}27.0 \\
11.5\end{array}$ \\
\hline COD $(\mathrm{mg} / \mathrm{L})$ & $\begin{array}{ll}12.8 & \pm \\
4.0 & \end{array}$ & $\begin{array}{l}19.1 \quad \pm \\
6.7\end{array}$ & $\begin{array}{l}26.1 \\
10.5\end{array}$ & $\begin{array}{ll}29.1 & \pm \\
8.8 & \end{array}$ & $\begin{array}{ll}24.8 & \pm \\
13.8 & \end{array}$ & $\begin{array}{l}23.0 \\
10.0\end{array}$ \\
\hline $\mathrm{SS}$ (mg/L) & $\begin{array}{ll}9.7 & \pm \\
1.5 & \end{array}$ & $\begin{array}{ll}17.7 & \pm \\
2.5 & \end{array}$ & $\begin{array}{l}36.1 \\
1.5\end{array}$ & $\begin{array}{ll}30.7 & \pm \\
7.8 & \end{array}$ & $\begin{array}{ll}28.8 & \pm \\
6.4 & \end{array}$ & $\begin{array}{l}34.3 \quad \pm \\
10.4\end{array}$ \\
\hline $\mathrm{TP}(\mu \mathrm{g} / \mathrm{L})$ & $\begin{array}{l}0.176 \pm \\
0.044\end{array}$ & $\begin{array}{l}0.185 \pm \\
0.037\end{array}$ & $\begin{array}{l}0.133 \pm \\
0.031\end{array}$ & $\begin{array}{l}0.149 \\
0.040\end{array}$ & $\begin{array}{l}0.137 \\
0.034\end{array}$ & $\begin{array}{l}0.121 \pm \\
0.048\end{array}$ \\
\hline
\end{tabular}

Table 2: water quality in detention pond

Nitrogenous nutrient transformation in wetlands mainly occurs by biological processes including magnification, nitrification, gentrification, nitrogen fixation, and nitrogen assimilation.For secondary treated sewage, the predominant forms of nitrogen might be ammonium and nitrate depending on aeration levels in secondary treatment processes. Nitrification and gentrification are generally indicated as the principal processes for nitrogen reduction $[7,8]$. In this study total nitrogen levels were fluctuated from upstream toward detention pond indicated nitrification and denitrification concurrently occurred in the sediment. Macrophytes may remove some nutrients through direct uptake and provide environments for more intense microbial activities. The vegetation in constructed wetlands also creates quiescent conditions for sedimentation as well as oxidation conditions for organic matter decomposition and nutrient 
Citation: Yeh TY, Chen KF, Lin CL (2014) Waste Removal and Oxygen Condition in a Natural Water Purification System. J Civil Environ Eng 4:

Page 3 of 4

transformation through bacterial activities from microbes suspended in the water column and attached around the root zones (Table 3).

\begin{tabular}{|c|c|c|c|c|c|c|}
\hline & A & B & C & D & $E$ & $F$ \\
\hline $\begin{array}{l}\text { Ammonia } \\
\text { nitrogen }\end{array}$ & $\begin{array}{ll}4.14 & \pm \\
1.73 & \end{array}$ & $\begin{array}{ll}3.35 & \pm \\
1.13 & \end{array}$ & $\begin{array}{ll}2.23 & \pm \\
1.26 & \end{array}$ & $\begin{array}{ll}1.07 & \pm \\
1.07 & \end{array}$ & $\begin{array}{ll}0.89 & \pm \\
0.3 & \end{array}$ & $\begin{array}{l}0.70 \\
0.22\end{array}$ \\
\hline TKN & $\begin{array}{ll}5.36 & \pm \\
1.97 & \end{array}$ & $\begin{array}{ll}5.01 & \pm \\
2.27 & \end{array}$ & $\begin{array}{ll}2.78 & \pm \\
1.34 & \end{array}$ & $\begin{array}{l}1.61 \quad \pm \\
0.63\end{array}$ & $\begin{array}{ll}0.77 & \pm \\
0.62 & \end{array}$ & $\begin{array}{l}0.67 \\
0.46\end{array}$ \\
\hline $\begin{array}{l}\text { Nitrate } \\
\text { nitrogen }\end{array}$ & $\begin{array}{ll}1.27 & \pm \\
0.57 & \end{array}$ & $\begin{array}{l}1.47 \\
0.79\end{array}$ & $\begin{array}{ll}0.87 & \pm \\
0.49 & \end{array}$ & $\begin{array}{ll}1.00 & \pm \\
0.42 & \end{array}$ & $\begin{array}{ll}0.27 & \pm \\
0.31 & \end{array}$ & $\begin{array}{l}0.31 \\
0.43\end{array}$ \\
\hline $\begin{array}{l}\text { Nitrite } \\
\text { nitrogen }\end{array}$ & $\begin{array}{ll}0.09 & \pm \\
0.01 & \end{array}$ & $\begin{array}{ll}0.32 & \pm \\
0.13 & \end{array}$ & $\begin{array}{ll}0.18 & \pm \\
0.1 & \end{array}$ & $\begin{array}{ll}0.17 & \pm \\
0.02 & \end{array}$ & $\begin{array}{ll}0.07 & \pm \\
0.07 & \end{array}$ & $\begin{array}{l}0.04 \\
0.03\end{array}$ \\
\hline $\begin{array}{l}\text { Total } \\
\text { nitrogen }\end{array}$ & $\begin{array}{ll}6.72 & \pm \\
2.47 & \end{array}$ & $\begin{array}{ll}6.8 & \pm \\
2.26 & \end{array}$ & $\begin{array}{ll}3.83 & \pm \\
1.98 & \end{array}$ & $\begin{array}{ll}2.78 & \pm \\
1.79 & \end{array}$ & $\begin{array}{l}1.11 \\
1.68\end{array}$ & $\begin{array}{l}1.02 \\
0.57\end{array}$ \\
\hline
\end{tabular}

Table 3: Nutrient observation results (mg/L).

\section{Sediment quality and ORP condition}

SOD results are show in Figure 2 the oxygen varied from benthic sediment to top water.

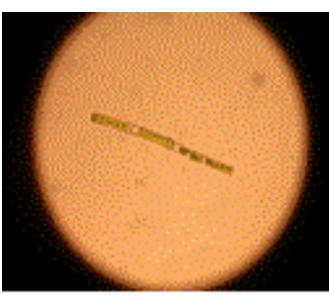

Oscillataria

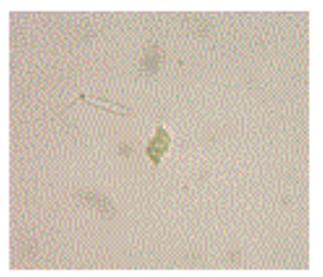

Synechocystis

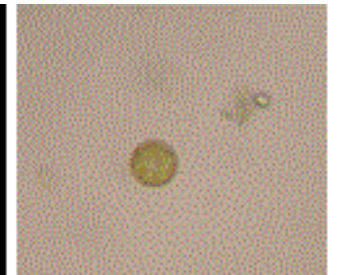

Scenedesmus

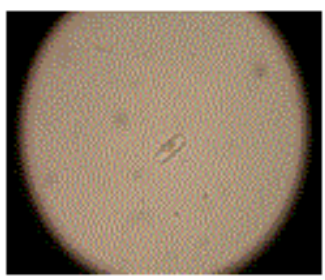

Navicula
Figure 2: Microscopic observation results.

\section{Algal species monitoring}

It is shown in Figure 3 most are algae and blue green algae. It indicated serious eutrophication.

\section{Sediment Monitoring}

\section{Particle size measurement}

The result of particle size measurement of three sampling point are showed in Figures 4 and 5. The sediment particle encompassed clay, silt, and sand with the particle size in the descending sequence as $<2$ $\mu \mathrm{m}, 2-50 \mu \mathrm{m}$ and $50-1000 \mu \mathrm{m}$. The greater particle of sand was expected to be easier to settle than silt and clay. Five sampling points from upstream to detention pond the total volume sand particles were in the decreasing order $74.08,13.38,3.1 \%$, respectively which indicated that most greater particles were settled in the upper stream sediment. Detent pond presented with higher total amounts of clay which possessed high cation exchange capacity (CEC) and pollutant adsorption in particular metal cation leading to higher metal mobility and bioavailability. This might be the cause that dissolved pollutants increased and impacted the benthic ecology.

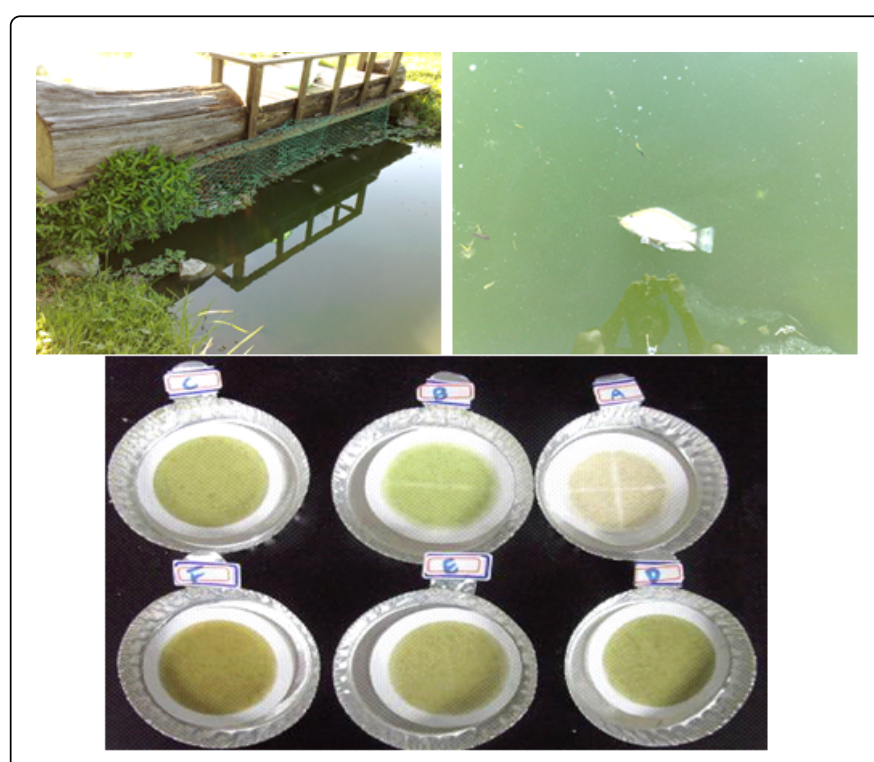

Figure 3: Fish kill events.

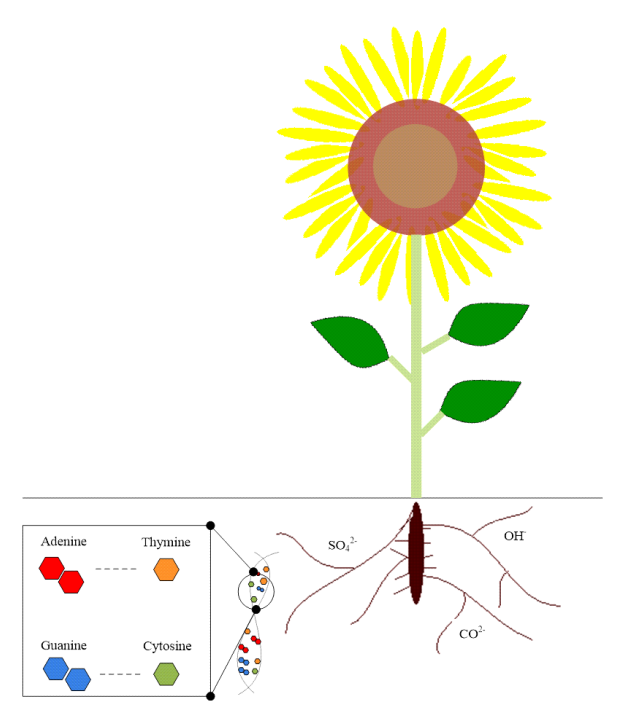

Figure 4: Schematic diagram of pot experiment.

\section{Conclusion}

Fish kill was commonly occurred in the detention pond and surface flow wetland due to algal bloom. Serious diurnal $\mathrm{DO}$ and $\mathrm{pH}$ were detected due to the photosynthesis and respiration to elevate DO and $\mathrm{pH}$ in the daytime and decreasing $\mathrm{DO}$ and $\mathrm{pH}$ at night. Oxygen levels fluctuation was the main caused of fish kill in this study site and leave 
Citation: Yeh TY, Chen KF, Lin CL (2014) Waste Removal and Oxygen Condition in a Natural Water Purification System. J Civil Environ Eng 4:

Page 4 of 4

out the possibility of toxic algae intrusion. SOD and OPR was revealed the black box regarding the oxic variation levels. Microbial PCR was conducted to illumine the species of microorganism in the sediment.The root of macrophytes was also investigation via SEM, EDX, and FTIR. The results of this study can be reference by other wetland for the future research and solve the emergent fish kill to be substitute of algaecide copper sulfate, a toxicant of phytoplankton application.

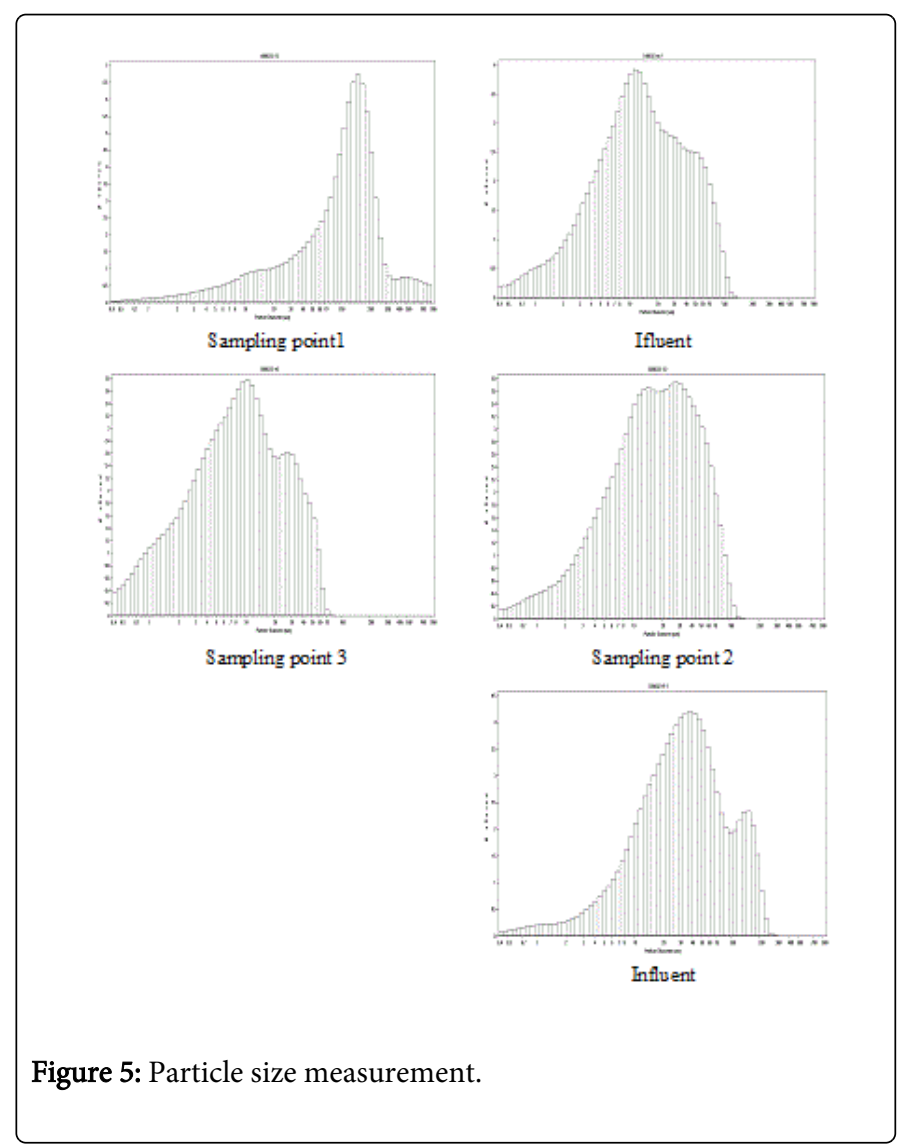

\section{Reference}

1. Yeh TY, Wu CH (2009) Pollutants removal within hybrid constructed wetland system in tropical regions. Water Science and Technology 59: 223-240.

2. Cheng H (2006) Cu (II) Removal from lithium bromide refrigerant by chemical precipitation and electrocoagulation. Separation and purification technology 52: 191-195.

3. Lan S, Ju F, Wu X (2012) Treatment of wastewater containing EDTA$\mathrm{Cu}$ (II) using the combined process of interior microelectrolysis and Fenton oxidation-coagulation. Separation and Purification Technology 89: 117-124.

4. Valipour M, Mousavi SM, Valipour R, Rezaei E (2013) Deal with Environmental Challenges in Civil and Energy Engineering Projects Using a New Technology. J. Civ. Env Eng. 3: 127.

5. Valipour M, Mousavi SM, Valipour R, Rezaei E (2013) A New Approach for Environmental Crises and its Solutions by Computer Modeling. In: The 1st International Conference on Environmental Crises and its Solutions, Kish Island, Iran.

6. Valipour M, Mousavi SM, Valipour R, Rezaei E (2012) Air, Water, and Soil Pollution Study in Industrial Units Using Environmental Flow Diagram. Journal of Basic and Applied Scientific Research. 2 (12), 12365-12372.

7. Reed SC, Crites RW, Middle brooks EJ (1995) Wetland System. Natural systems for waste management and treatment, 2nd, McGraw-Hill, New York.

8. Ju F, Hu Y, Cheng J (2011) Removal of chelated Cu (II) from aqueous solution by adsorption-coprecipitation with iron hydroxides prepared from microelectrolysis process. Desalination 274: 130-135. 